Matematikai Közlemények

IV. kötet, 2016

doi:10.20312/dim.2016.02

\title{
Gömbközelítések poliéderekkel
}

\author{
Talata István \\ Szent István Egyetem, \\ Ybl Miklós Építéstudományi Kar, Budapest, \\ és Dunaújvárosi Egyetem, Dunaújváros \\ talata.istvan@ybl.szie.hu
}

\begin{abstract}
ÖSSZEFOGLALÓ. Áttekintünk néhány módszert, melyekkel gömböt jól megközelítő poliéderek készíthetők el. Egyrészt bizonyos geodézikus poliédereket, másrészt ún. Goldberg-poliédereket állíthatunk így elő. Történetuik, alkalmazásaik, és néhány, a geometria oktatásában hozzájuk kapcsolódó tapasztalat is bemutatásra kerül.
\end{abstract}

ABSTRACT. We review some methods to construct polyhedra approximating a sphere. On the one hand, some geodesic polyhedra, and on the other hand, some Goldberg polyhedra can be constructed this way. Their history, applications, and some experience in geometry education in connection with them are also presented.

\section{Gömbközelítések geodézikus poliéderekkel}

A geodézikus poliéderek olyan, csak háromszöglapokkal rendelkező poliéderek, amelyek egy gömböt közelítenek meg, és amelyeknek minél több csúcsuk van, a lapjaik annál kisebb átméröjüek, ezért így alakjuk egy gömb egyre jobb közelítései. A geodézikus poliéderekre egy közkeletü (de nem túl precíz) elnevezés a geodézikus gömb, amely amiatt terjedhetett el, mert ezek a poliéderek gömbök közelítései. Geodézikus kupolán pedig olyan, csak háromszög-lapokból álló poliéderfelületet értünk, amely egy félgömb, vagy általánosabban egy gömbszelet gömbfelületi részét közelíti meg, tehát egy geodézikus poliéder sokszöglapjainak olyan részhalmazát, amely egy gömbfelület (síkkal történt) szelését közelíti meg.

A „geodézikus" szó a geodézikus poliéderek nevében arra utal, hogy egy ilyen poliéder egy gömböt közelít meg, melynek geodézikus (elterjedtebb magyar fordításban: geodetikus) vonalai a fökörök, míg az ilyen poliéderek élei fökörívek közelítései, és a csúcsok számának növelésével ahogy egy ilyen poliéder egyre jobban közelíti a gömböt, úgy adott hosszúságú főkörívek egyre több élből álló közelítéseként jelennek meg a geodézikus poliéder bizonyos éleinek sorozatai.

Ezt szemléletesen úgy is meg lehet fogalmazni, hogy ha a geodézikus poliéder által közelített gömb felületére rávetítjük a gömbközéppontból a poliéder élhálóját, akkor vonalak olyan, főkörívekből álló családját kapjuk a gömbfelületen, amelyben az egymást metsző főkörívek háromszögtartományokra osztják a gömbfelületet. A gömbfelület ilyen felosztását geodézikus rácsnak nevezik.

Egy $n$-edrendü geodézikus poliéder rekurzívan definiálható (tetszőleges $n \geq 1$ esetére), mint egy $(n-1)$-edrendü geodézikus poliéder háromszöglapokkal történő finomítása. A következőkben néhány eljárást mutatunk $n$-edrendủ geodézikus poliéderek elkészítésére, és ezeket a poliédereket azonosítjuk határoló lapjaiknak $\mathcal{L}_{n}$ családjával. 
Legyen $c$ egy $B$ gömb középpontja, és legyen $H$ egy háromszöglap, $c \notin H . \pi(H)$ legyen az a háromszöglap, melynek csúcsai $H$ csúcsainak a $c$ pontból a $B$ gömb felületére vetített képei. Ha $\mathcal{L}$ háromszögek egy családja, akkor legyen $\pi(\mathcal{L})=\{\pi(H) \mid H \in \mathcal{L}\}$. Tehát $\pi(\mathcal{L})$ háromszögek olyan családja, melyek csúcsai a $B$ gömb felületén fekszenek.

Legyen $P_{0}$ egy konvex poliéder, $c \in$ int $P_{0} \subseteq B$, ahol int $P_{0}$ jelöli $P_{0}$ belsejét (pl. $P_{0}$ lehet egy $B$-be írt szabályos test vagy archimédeszi test). Legyen $\mathcal{L}_{0}$ a $P_{0}$ poliéder lapjainak a családja.

Bontsuk fel az $\mathcal{L}_{0}$ minden egyes háromszögtöl különböző lapját a lapok súlypontjaiból, mint közös csúcsból annyi háromszögre, amennyi a lap oldalszáma. Legyen $\mathcal{L}_{0}^{\prime}$ az így keletkezett háromszögek és $\mathcal{L}_{0}$ háromszöglapjainak az összeségének a családja. Legyen $\mathcal{L}_{1}=$ $\pi\left(\mathcal{L}_{0}^{\prime}\right)$. Azaz $\mathcal{L}_{1}$ háromszögeknek egy olyan családja, melyek csúcsai a $B$ gömb felületén fekszenek.

Szemléletesen, $\mathcal{L}_{1}$ konstrukciója elképzelhető úgy is, hogy a $P_{0}$ poliéder háromszögtől különböző lapjaira gúlákat állítunk (úgy, hogy a gúlák csúcsainak $c$ gömbközéppontból a lapra vett vetületei a lapok súlypontjai legyenek), ezeket egyesítjük a $P_{0}$ poliéderrel, majd az így keletkező poliéder határolólapjait (melyek mind háromszögek) olyan síkokra vetítjük $c$ böl, hogy minden csúcsuk a $B$ gömb felületén legyen - így kapjuk $\mathcal{L}_{1}$-et.

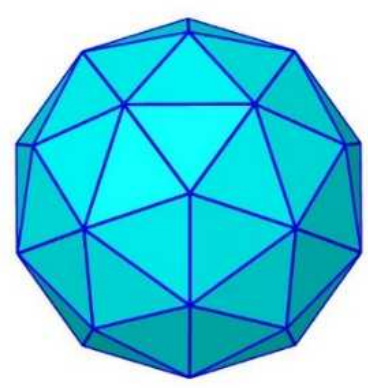

1. ábra. Geodézikus dodekaéder L1

Többféle eljárás is létezik, mellyel $n$-edrendü geodézikus poliédert készíthetünk egy $(n-1)$-edrendü, csak háromszöglapokat tartalmazó geodézikus poliéderből (amikor $n \geq 2$ ), most csak a két legegyszerübbet emeljük ki. Mindegyik esetében először az $(n-1)$-edrendü geodézikus poliéder lapjait bontjuk fel kisebb háromszögekre, majd ezeknek a csúcsait módosítjuk úgy, hogy mindegyik a $B$ gömb felületén legyen. A két eljáráshoz tartozó lapfelbontások:

1. Egy háromszöglap oldalfelezö pontjait berajzolva négy, az eredeti háromszöglappal hasonló háromszögre bontunk fel egy háromszöglapot (ld. 2. ábrát).

2. Egy háromszöglap oldalfelezö pontjait és súlypontját berajzolva hat olyan kisebb háromszögre bontjuk fel a háromszög-lapot, melyeknek az egyik csúcsa a háromszöglap valamelyik csúcsa, másik csúcsa egy oldalfelezö pontja, harmadik csúcsa pedig a súlypontja (ld. 3. ábrát).

Az 1. vagy 2 . háromszögfelbontási eljárások valamelyikét az $\mathcal{L}_{n-1}$ lapcsalád $(n \geq 2)$ minden elemére elvégezve, háromszöglapoknak egy $\mathcal{L}_{n-1}^{\prime}$ családját kapjuk.

Legyen $\mathcal{L}_{n}=\pi\left(\mathcal{L}_{n-1}^{\prime}\right)$. Ezzel az $n$-edrendü geodézikus poliéder rekurzív definiálását befejeztük, mivel a poliédert azonosítjuk a határoló lapjainak $\mathcal{L}_{n}$ családjával (tetszőleges $n \geq 1$ esetére). 

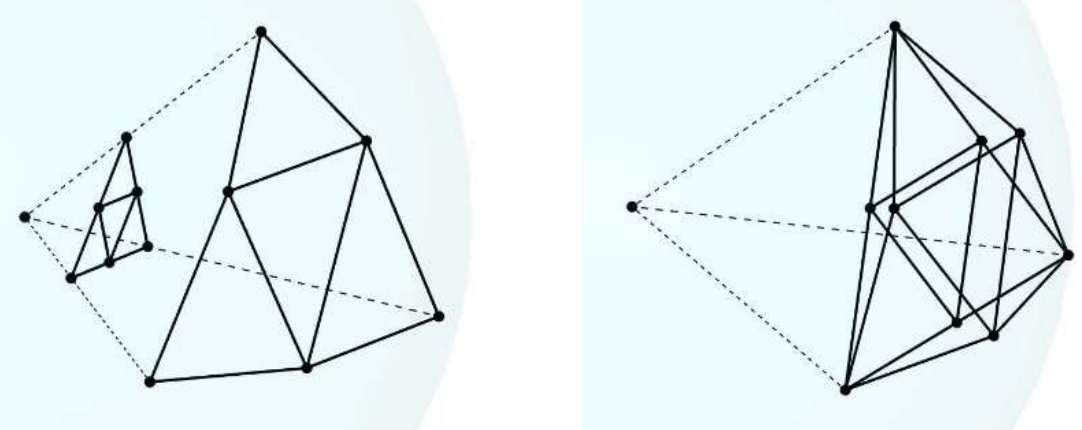

2. ábra. Az 1. eljárás szerinti háromszögfelbontás és gömbi vetítés gömb belsejében, ill. gömb határán levő háromszögcsúcsok esetén
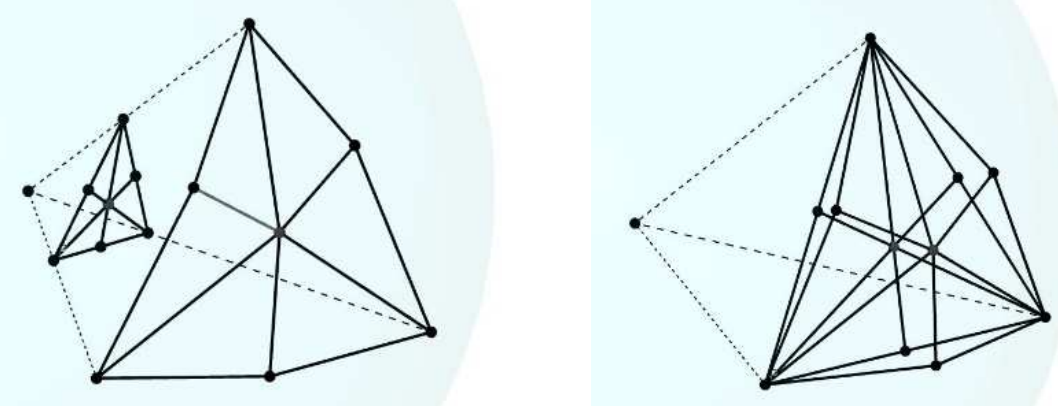

3. ábra. A 2. eljárás szerinti háromszögfelbontás és gömbi vetítés gömb belsejében, ill. gömb határán levő háromszögcsúcsok esetén.

Ha úgy kapunk $n$-edrendü geodézikus poliédert, hogy csak az 1. eljárást alkalmazzuk (egymás után $(n-1)$-szer), akkor Ln típusú geodézikus poliéderről beszélünk, ha pedig csak a 2. eljárást alkalmazzuk (egymás után $(n-1)$-szer), akkor LnT típusú geodézikus poliéderről (példákat láthatunk erre a 4-6. ábrákon, ahol szabályos ikozaéder, ill. dodekaéder a $P_{0}$ alaptest, és körülírt gömbjük $\left.B\right)$, ld. [1]. A többi eljárás felsorolása megtalálható [2]-ben (ld. még [3]).
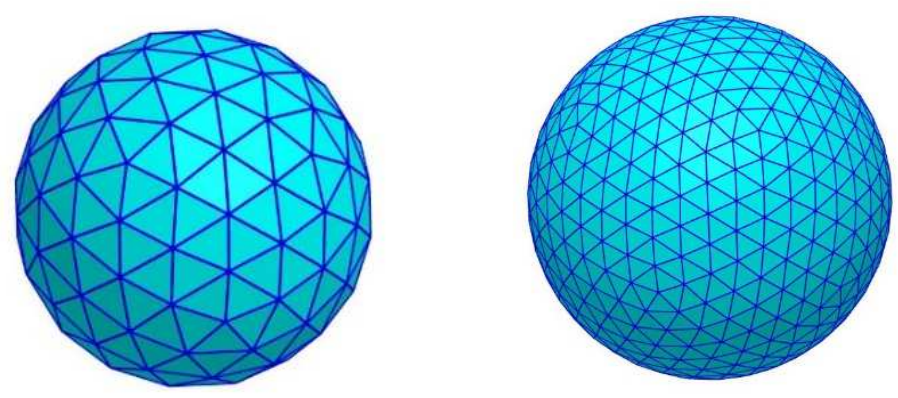

4. ábra. Geodézikus dodekaéderek L2 és L3 

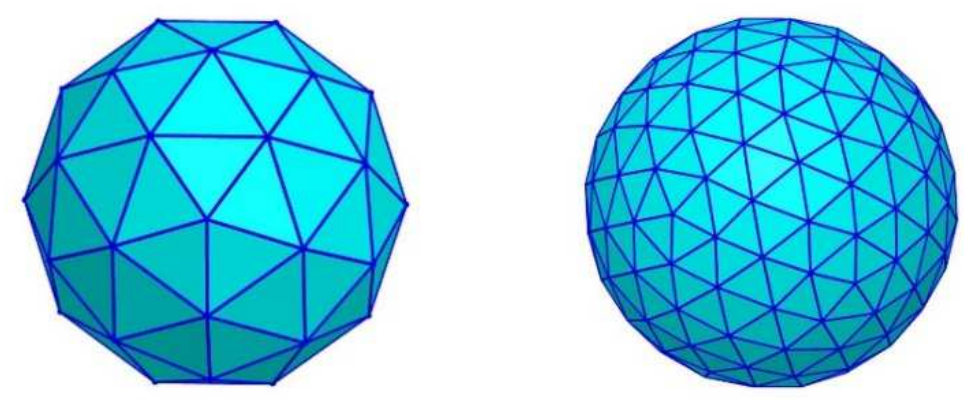

5. ábra. Geodézikus ikozaéderek L2 és L3
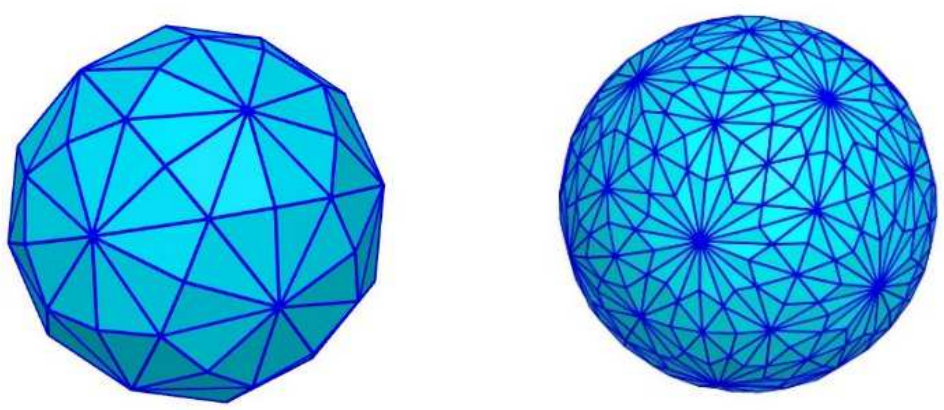

6. ábra. Geodézikus ikozaéderek L2T és L3T

Ha van olyan sík, amely kettészel egy geodézikus poliédert úgy, hogy nem metsz bele egyik lapjának a relatív belsejébe sem, akkor az így keletkezett részek geodézikus kupolák, ld. 7. ábrát (a klasszikus esetben, amikor félgömbhöz tartozó kupolát tekintünk, éppen a gömbközépponton átmenő sík szeli ketté a geodézikus poliédert úgy, hogy nem metsz bele egyik lapjának a relatív besejébe sem, de ilyen sík nem mindig létezik egy adott geodézikus poliéderre).

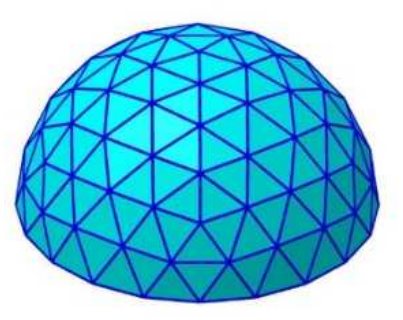

7. ábra. Geodézikus ikozaéder kupola L3

Megjegyzendő, hogy az Ln eljáráshoz nagyon hasonló a még Fuller által bevezetett $n \mathrm{~V}$ eljárás, ld. [1]-[3] (ez egyetlen lépés, nem többszöri ismétlése egy eljárásnak): Ekkor a $P_{0}$ alappoliéderből képzett L1 típusú poliéder mindegyik háromszöglapját úgy osztjuk fel vele hasonló, kisebb háromszögekre, hogy a háromszöglap éleit $n$ egyenlő részre osztjuk fel, és az osztópontokon átmenő, a lap oldalaival párhuzamos egyenesek határoznak meg egy háromszöglapfelosztást. 
Az összes lapra elkészítve ezt a felosztást, egy $\mathcal{L}_{n}^{\prime}$ családját kapjuk háromszögeknek. Ezek csúcsait vetítjük a $c$ gömbközéppontból a $B$ gömb felületére, és az ezekhez a vetületi pontokhoz tartozó háromszöglapok $\mathcal{L}_{n}=\pi\left(\mathcal{L}_{n}^{\prime}\right)$ családja határozza meg az $n \mathrm{~V}$ geodézikus poliédert.

Tehát ugyanazon $P_{0}$ alappoliéder esetén az L2 és $2 \mathrm{~V}$ geodézikus poliéderek megegyeznek, és $n=2^{k-1}$ (ahol $k \geq 2$ egész szám) esetén az L $k$ és $n V$ poliéderek laphálója kombinatorikailag ekvivalens (azaz ugyanolyan elrendezésủ és illeszkedésủ lapokból állnak, de az élhosszak különbözők lehetnek).

Elmondható, hogy általában az $n \mathrm{~V}$ típusú geodézikus poliéderek esetén jóval többféle élhossz fordul elö, mint az $L k$ típusú poliéderek esetén, ha ugyanaz a $P_{0}$ alappoliéderük és $n=2^{k-1}$ (azaz kombinatorikailag ekvivalensek a laphálóik), és ez még inkább így van, ha az alappoliéder szabályos vagy archimédeszi test.

Gömböt közelítő, csak háromszöglapokkal rendelkező poliéder esetén az ideális az lenne, amikor csak egyféle élhossz fordul elő az éleknél (mert ekkor a legegyszerübb az élszerkezet megvalósítása). Ekkor a poliéder minden lapja szabályos háromszög lenne. Az ilyen poliédereket deltaédereknek nevezik, és ismert, hogy csak véges sok (nevezetesen 8-féle) konvex deltaéder létezik, pl. legfeljebb 20 csúcsuk lehet.

Tehát, ha gömbnek akármilyen jó poliéderközelítésére szeretnénk konstrukciót adni háromszöglapú konvex poliéderekkel, akkor biztosan tudható, hogy legalább kétféle élhosszúság fog szerepelni a poliéder élhosszai között 20 csúcsszám fölött.

\section{Gömbközelítés mértéke}

Precízen definiálható, hogy mit értünk azon, hogy egy poliéder alakja jól közelít gömböt. Ha egy $P$ poliéder körülírt és beírt gömbjei $B_{1}$ és $B_{2}$, akkor ezek $r_{1}$ és $r_{2}$ sugarainak az $r_{1} / r_{2}$ hányadosa alapján meghatározható a gömbközeli alak mértéke (körülírt gömbön a $P$-t tartalmazó legkisebb sugarú gömböt értjük, beírt gömbön pedig egy, a $P$-ben elhelyezhető lehetö legnagyobb sugarú gömböt).

Nevezetesen, minél közelebbi ez a hányados 1-hez, annál jobban közelíti $P$ alakja egy gömb alakját.

Geodézikus poliéderek esetén azért mondjuk, hogy alakjuk jól közelíti a gömbét, mert bármely alaptestből kiindulva, valamely elkészítési eljárásukat megfelelően sokszor alkalmazva, az adódó geodézikus poliéderre az $r_{1} / r_{2}$ hányados tetszólegesen közel lesz 1-hez, ha a csúcsszámuk tart végtelenhez.

Ez az L $n$ és LnT geodézikus poliéderkonstrukciók esetében azért van így, mert az ilyen poliéderek körülírt gömbje egy fix gömb, míg az élhosszaik, és így a háromszöglapjaik átmérői is egyre közelebb kerülnek 0-hoz, emiatt a beírt gömbjeik sugarai egyre közelebbiek a körülírt gömb sugarához, ahogy $n$ növekszik.

1. Megoldatlan probléma. Ha egy 3-dimenziós konvex poliédernek minden lapja háromszög, és $k$-féle élhossz fordul elö az élei esetében, valamely $k$ egész számra $(k \geq 2)$, akkor mennyire közelítheti meg a poliéder alakja egy gömb alakját, azaz az $r_{1} / r_{2}$ hányados (amely a körülírt gömbje sugarának és a beírt gömbje sugarának a hányadosa) mennyire lehet közel 1-hez?

Mivel legalább kétféle élhossz esetén lehet akármilyen sok csúcsa egy poliédernek, ezért nem igaz, hogy csak véges sok poliéder vizsgálata elégséges az előbbi kérdés megválaszolásához.

2. Megoldatlan probléma. Egy tetszőleges $\varepsilon>0$ szám esetén legalább mekkora egy tetszőleges, csupa háromszöglappal rendelkező, 3-dimenziós konvex poliéderre kiszámított 
$H / h$ hányados, ahol $H$ a poliéder leghosszabb élének, $h$ a poliéder legrövidebb élének a hossza, ha fennál, hogy a poliéderre az $r_{1} / r_{2}$ hányados (amely a körülírt gömbje sugarának és egy beírt gömbje sugarának a hányadosa) legfeljebb $(1+\varepsilon)$ ?

\section{A geodézilkus kupolák és geodézilkus poliéderek története}

Geodézikus kupolát elsőként Walther Bauersfeld tervezett a jénai planetáriumba, amelynek első verzióját a Zeiss Mủvek egyik épületének a tetejére építették 1923-ban, majd ezután egy nagyobb, szintúgy geodézikus kupolával rendelkező, de önálló épületben elhelyezett planetáriumot is tervezett, ez 1926-ban nyílt meg a látogatók előtt.

A geodézikus kupolák és geodézikus poliéder szerkezetű épületek Richard Buckminster Fuller népszerüsítésében váltak közismertté, ő valószínűleg Bauersfeldtől függetlenül újra felfedezte a geodézikus kupolákat, valamint a geodézikus poliédereket, és azokra többféle lehetséges elkészítési eljárást is szisztematikusan feltérképezett.

Buckminster Fuller az 1940-es évek második felétől foglalkozott ezzel a témakörrel, és 1954-ben az USA-ban szabadalmaztatott is bizonyos típusú geodézikus kupolákat. Továbbá, az általa alapított cégeken keresztül több ezer, geodézikus kupola és geodézikus poliéder szerkezetủ épület megvalósításában közreműködött.

Az 1960-as években volt a geodézikus kupolák és poliéderek fénykora, pl. az 1967-es Montreáli Expo amerikai pavilonja is egy Buckminster Fuller tervei alapján készült geodézikus kupola volt.

A balatonboglári Xantus János Gömbkilátó fémszerkezete egy geodézikus poliéder élváza, ez a Kádár István által az 1963-as BNV-re tervezett Magyar Atomium, a belföldi idegen-forgalom pavilonjának a háromszöglemezektől megfosztott, és Városligetből Balatonboglárra szállított szerkezete, melyet az 1958-as Brüsszeli Világkiállítás jelképévé vált Atomium ihletett.

A Gömbkilátó poliéderszerkezete az ún. geodézikus dodekaéder L2 poliédernek felel meg (1d. 4. fejezetet), 240 háromszöglapból, 360 élből és 122 csúcsból áll. Négyféle hosszúságú él alkotja az élvázát, ezek kétféle háromszöglapot határoznak meg. A leghosszabb él a legrövidebb élnél kb. 16\%-kal hosszabb csupán. A poliéder mindegyik csúcsában 6 él találkozik, kivéve 12 csúcsot, amelyekben pontosan 5 él találkozik - ezek egy szabályos dodekaéder csúcsainak az irányában helyezkednek el.

\section{Gömbközelítés Goldberg-poliéderekkel}

Goldberg-poliéderen olyan konvex poliédert értünk, amelynek ikozaéderes forgási szimmetriája van, minden lapja ötszög vagy hatszög, és egy csúcsban három lap találkozik.

A geodézikus poliéderek közül soknak a duálisa (pontosabban: körülírt gömbjükhöz tartozó poláris poliédere) egy Goldberg-poliéder (ld. 8. ábra), pl. amikor ikozaéder vagy dodekaéder alaptestből indulunk ki, és az ikozaéderes forgásszimmetriát, valamint a konvexitást megőrizzük a geodézikus poliéder elkészítése során, akkor ilyen poliédert kapunk - tehát a geodézikus dodekaéder Ln és geodézikus ikozaéder Ln poliéderek esetében ez a helyzet, amikor $2 \leq n \leq 3$.

Olyan esetekben, amikor egy poliéder minden csúcsa a körülírt gömbjének a felületén található, a poliédernek ehhez a gömbhöz tartozó poláris poliédere megkapható, mint a poliéder csúcsaihoz húzott, a körülírt gömböt érintő síkok ezen gömböt tartalmazó féltereinek metszete, ha a gömb sugara 1 - más gömbsugár esetén pedig még az így (félterek metszeteként) keletkezett poliéderre egy olyan középpontos hasonlóságot kell alkalmazni, melynek arányossági tényezője $1 / r^{2}$ és középpontja a körülírt gömb középpontja, ahol $r$ a 
kiindulási poliéder körülírt gömbjének a sugara. A poláris poliéder laphálója a kiindulási poliéder duálisa, így egy konvex geodézikus poliéder olyan csúcsához, melyben 6 él fut össze, annak poláris poliéderében egy hatszöglap tartozik, ill. a geodézikus poliéder egy-egy háromszöglapjához a poláris poliéderében egy-egy olyan csúcs tartozik, ahol pontosan három poliéderlap találkozik.

Mivel geodézikus poliéderek poláris poliédereinek a beírt gömbjük érinti a lapjaikat, ezért az így készített Goldberg-poliéderek jó gömbközelítések, hiszen a lapjaik átmérői tartanak 0-hoz, ha a lapjaik száma tart végtelenhez.
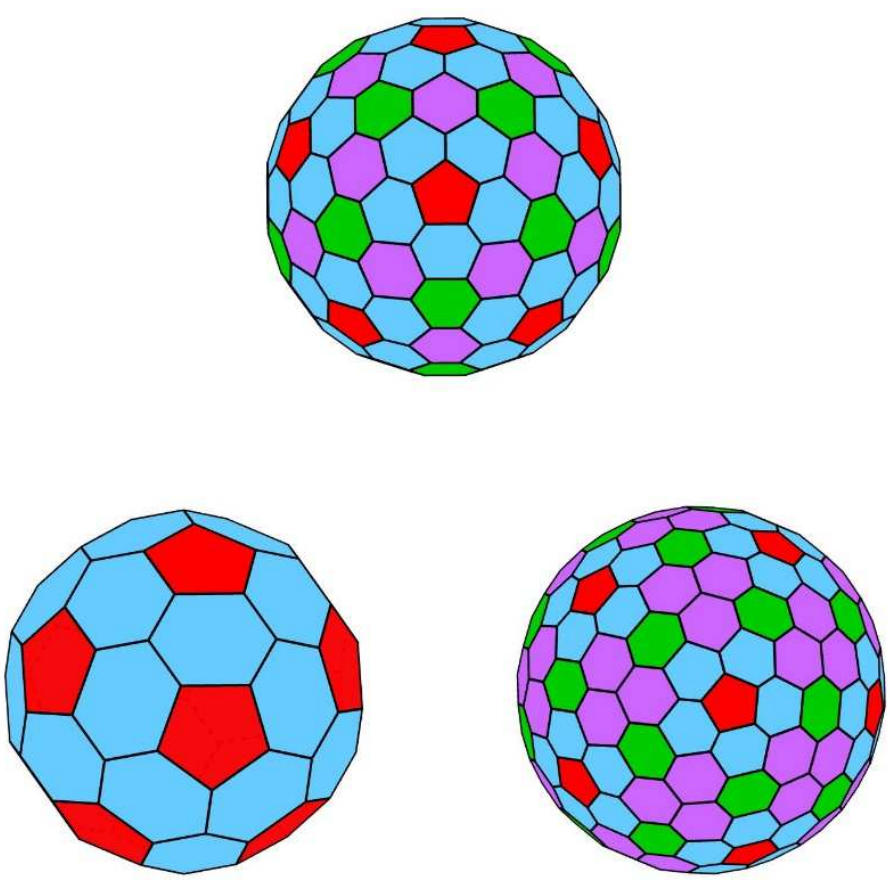

8. ábra. Goldberg-poliéderek: poláris poliéderei a geodézikus dodekaéder L2, geodézikus ikozaéder L2 és L3 poliédereknek

A kémiában is feltünik bizonyos (a nanotechnológiában alkalmazható) molekulák kapcsolata a geodézikus poliéderekkel: a fullerének olyan szénmolekulák, melyek egyes típusai gömbhéjszerkezetüek, azaz egy gömb felületéhez közel elhelyezkedő atomokkal rendelkeznek, elég nagy üres térrészt közrezárva - ezeknek a molekuláknak sok érdekes tulajdonságuk van. Az elsőként talált ilyen molekula, a Buckminsterfullerén-C60 (amely focilabda alakú) 1985-ös felfedezéséért 1996-ban kémiai Nobel-díjat kapott H. Kroto, R. Curl és R. Smalley. Azóta már találtak olyan fullerént is (a C240 jelüt), amely 240 szénatomból áll, és szerkezete a balatonboglári Gömbkilátó geodézikus poliéderének duálisa (pontosabban: poláris poliédere) - ez egy Goldberg poliéder.

\section{Poliéderek a SZIE YMÉK építész hallgatóinalk geometria oktatásában}

A Szent István Egyetem Ybl Miklós Építéstudományi Karán tartott Számítógépes térgeometriai modellezés szabadon választható tárgy tematikájában nagy hangsúllyal szerepel a poliéderek témaköre. A Számítógépes térgeometriai modellezés tárgy építész hallgatói korábbi tanulmányaik alapján általában már jól ismerik a szabályos testeket, és alapozó CAD kurzuson azok modellezését is elsajátították. A térgeometria kurzuson mindezen túlmenően, 
megismerkednek az archimédeszi testekkel és a Johnson poliéderekkel, valamint azok számítógépes modellezését is megtanulják: szabályos sokszöglapok megfelelö (térben kiszerkesztett) szögben való felhajtásával készítik el ilyen poliédereknek a csúcsalakzatait, amely lépés után az egész poliéder elkészítése már nem nehéz. Elsajátítják azt is, hogy ehelyett szelések (csonkolások) és eltolások (testek vagy lapok eltolásai) is alkalmazhatók bizonyos archimédeszi testek elkészítésekor, alkalmasan választott szabályos testből kiindulva.

A térgeometria tantárgyi tematikában szerepel az is, hogy archimédeszi test csúcsait felhasználva egymást metsző sokszöglapok vagy csillagsokszöglapok csúcsaiként, uniform csillagpoliédereket készíthetünk.

A hallgatók által a szabályos testekre már megismert dualitás fogalmat kiterjesztjük archimédeszi poliéderek duális poliédereinek a meghatározására is, a körülírt gömbjükhöz tartozó poláris poliéderüket elkészítve állítunk elő ilyen poliédereket.

A kurzusokon a CAD modellezés AutoCAD szoftverrel történik, emellett dinamikus geometriai szoftvereket (Cabri 3D, GeoGebra) is használunk poliéder-modellezésre. Ez utóbbi esetekben a szabályos testek már elérhetök közvetlen paranccsal, illetve a szoftverre sajátosan jellemző eszközökkel is kombinálhatjuk a fentebb említett poliéderek elkészítését, pl. Cabri 3D esetében konvex burok eszköz is használható, GeoGebra esetében pedig objektumok (pl. csúcsok, lapok) sorozata készíthető el akár egyetlen paranccsal.

Egy poliéder laphálójának dinamikus kinyitása/becsukása is megvalósítható a nevezett dinamikus geometriai szoftverekkel - akár egy ennek megfelelő eszköz behívásával (Cabri 3D-ben konvex poliéderek esetén, GeoGebrában pedig gúla, hasáb, szabályos testek esetén), akár a felhasználó által elkészítve, sokszöglapok megfelelő forgatásait megvalósítva, a forgatási szögeket alkalmasan változtatva.

\section{Geodézilkus poliéderek modellezése}

A 2015/16-os tanévben a geodézikus poliéderek modellezése is bekerült a Számítógépes térgeometriai modellezés tárgy tematikájának poliéderekkel foglalkozó tananyagrészébe, mivel építészeti szempontból is érdekes, önhordó szerkezetekkel bírnak azok az építmények, melyek szerkezete geodézikus poliédernek, vagy geodézikus kupolának az élváza.

Geodézikus poliédereknek, ill. kupoláknak a számítógépes modellezésekor olykor hatékonyan lehet alkalmazni geometriai transzformációkat, mivel ha szabályos test vagy archimédeszi test laphálójának finomításaként készítünk el egy geodézikus poliédert, akkor egy megfelelő poliéderrész elkészítése után, alkalmasan (a kiindulási test szimmetriáihoz tartozó) választott forgatásokat, tükrözéseket alkalmazva az egész geodézikus poliéder felszínét megkaphatjuk. Ezáltal geodézikus poliéderek készítése közben a hallgatók elmélyíthetik ismereteiket a geometriai transzformációk témakörében, és a poliéderek alaptulajdonságait is jobban elsajátíthatják.

Az egyes szoftverek esetében sajátságos problémák jönnek elő a geodézikus poliéderek modellezésekor, ill. egyes fogások sokkal könnyebben megvalósíthatók bizonyos szoftverekkel, mint másokkal.

AutoCAD szoftver esetén nehézkes a gömbfelületre vetítés, ehhez gömbfelület és félegyenes metszéspontját kell megszerkeszteni. Azonban a gömb sugarának és a félegyenes irányának ismeretében a metszéspont könnyen megszerkeszthető.

Cabri 3D esetén nincs lehetőség több alakzat egyidejü transzformációjára vagy több transzformációra egy lépésben (ld. mint a poláris kiosztás AutoCAD-ben, vagy a listamüveletek GeoGebrában). Csúcsok vagy poliéderek konvex burka ellenben könnyen képezhető, de vigyázni kell, mert az LnT típusú geodézikus poliéderek nem mindig konvexek! 
A GeoGebra az alappoliédereken (hasáb, gúla, szabályos testek) kívül más poliédert nem tud kezelni poliéderként, de sokszöglapok listájaként lehet kezelni ezeket. Poliéder síkkal való szelését sem ismeri a Geogebra, de poliéder sokszöglapjait lehet síkkal metszeni.

\section{Oktatási tapasztalat}

A Számítógépes térgeometria kurzusok hallgatói a 2015/16 tanévben szívesen foglalkoztak geodézikus poliéderekkel, pedig házi feladatot is kaptak ebből a témakörböl. Általában Cabri 3D szoftverrel dolgoztak a legszívesebben, még ha itt egyesével is kellett minden transzformációt végrehajtani az egész poliéder elkészítéséhez (de szerencsére a konvex burok képzés lehetősége miatt egyre nagyobb és nagyobb poliéderrésszel dolgozhattak). Meglepődtek, amikor egy LnT típusú geodézikus poliéderre az jött ki, hogy nem konvex (ekkor a konvex burok képzést óvatosan, megfelelő poléderrészekre lehetett csak alkalmazni Cabri 3D-ben).

Mindegyik használt szoftverre igaz volt, hogy több száz lapú geodézikus poliédert lehetett velük aránylag kényelmesen elkészíteni, de a többezer lapú poliéderek modellezése már szoftveres problémákba ütközött. A térbeli szerkesztés során ügyelniük kellett rá, hogy a poliéder lapjainak minden oldalát másik lap határolja, és két lapnak közös éle vagy közös csúcsa lehet, más közös részük nem lehet. A hallgatók változatosan használtak forgatásokat, síkra, egyenesre és pontra vonatkozó tükrözéseket a geodézikus poliéderek elkészítéséhez, sokszor azt is figyelembe véve, hogy egy adott szoftver esetén egy bizonyos nézetben melyik a legkönnyebben megvalósítható müvelet.

Összeségében hasznosnak gondolom a geodézikus poliéderek témakörének a bevonását a tantárgy tematikájába, a való élethez és az építészethez való közvetlen kapcsolata miatt, valamint mert a hallgatók számára a poliéderek és a geometriai transzformációk tulajdonságainak jobb megértésére, és a virtuális térbeli modellező munka révén a térlátásuk fejlesztésére adott lehetöséget.

\section{Köszönetnyilvánítás}

Szeretném megköszönni Németh Lászlónak, hogy erről a témakörről előadhattam Sopronban a Matematika Oktatása és Kutatása Szeminárium (MOKUS) 2016-os programjában.

\section{Irodalomjegyzék}

[1] Mueller, R. K., Geodesic Polyhedra, at http://simplydifferently.org/Geodesic_Polyhedra, 2007 (last updated in 2012).

[2] Popko, E. S., Divided Spheres: Geodesics and the Orderly Subdivision of the Sphere, CRC Press, Boca Raton, FL, 2012.

[3] Pugh, A., Polyhedra: A Visual Approach, University of California Press, Berkeley, CA, 1976. 